\title{
Chemical attributes of a remineralized Oxisol
}

\author{
Rafael CIpriano da Silva ${ }^{1}$ Marina Elias Cury ${ }^{3}$ João José Cardinali Ieda ${ }^{3}$ Renata Alcarde Sermarini ${ }^{2}$ \\ Antonio Carlos de Azevedo ${ }^{{ }^{*}}$
}

'Departamento de Solos e Nutrição de Plantas, Escola Superior de Agricultura "Luiz de Queiroz" (ESALQ), Universidade de São Paulo (USP), 13418-900, Piracicaba, SP, Brasil. E-mail: aazevedo@usp.br. *Corresponding author.

${ }^{2}$ Departamento de Ciências Exatas, Escola Superior de Agricultura “Luiz de Queiroz” (ESALQ), Universidade de São Paulo (USP), Piracicaba, SP, Brasil.

${ }^{3}$ Escola Superior de Agricultura “Luiz de Queiroz” (ESALQ), Universidade de São Paulo (USP), Piracicaba, SP, Brasil.

\begin{abstract}
Remineralizers are comminuted rocks that are applied to soil, and their use as an agricultural amendment was regulated in Brazil in 2013. However, mechanisms of action of these materials must be better known to enable them to be best used in agricultural fields. Soil chemical attributes of an Oxisol were monitored after the application of a diabase remineralizer. The increase in exchangeable Na observed was associated with the dissolution of the border of the plagioclase crystals where this element is highly concentrated (albite). Therefore, it was inferred that the time since the application of the remineralizer (1 to 2 years depending on the treatment) was not sufficient to exhaust this crystal volume. Unfortunately, the presence of several sources of Ca-containing minerals in the remineralizer did not allow to infer if the calcic nuclei was dissolving. An increase in effective cation exchange capacity was observed without the concurrent increase in the pH of the soil. The two non-exclusive hypotheses proposed to explain this result were that an extra surface charge has originated on the surface of the newly precipitated oxidic phases and/or from the dissolution of the remineralizer grains. Rapid precipitation of amorphous solids (as measured by the increase in $\mathrm{Al}_{0}$ and $\mathrm{Fe}$ ) would also explain the lack of increase in exchangeable $\mathrm{Fe}$ and Al despite the large amount of $\mathrm{Al}_{2} \mathrm{O}_{3}$ $(11.90 \%)$ and $\mathrm{Fe}_{2} \mathrm{O}_{3}(14.45 \%)$ in the remineralizer.

Key words: rock powder, mineral dissolution, cation exchange capacity.
\end{abstract}

Atributos químicos de um Latossolo remineralizado

RESUMO: O uso de remineralizadores como insumo agrícola foi regularizado em 2013, mas seus mecanismos de ação precisam ser melhor conhecidos para viabilizar o manejo nos campos agrícolas. Atributos químicos de um Latossolo foram monitorados após remineralização com diabásio. O aumento de Na trocável foi atribuído à dissolução das bordas dos plagioclásios (albita) onde a concentração deste elemento é maior. Infelizmente, não é possivel especular se o tempo decorrido desde a aplicação (um a dois anos, dependendo do tratamento) foi suficiente para solubilizar o núcleo cálcico (anortita) destes cristais, já que o remineralizador possui outros minerais fonte de Ca. Houve aumento da capacidade de troca cationica efetiva sem aumento do pH. As hipóteses propostas para explicar este fenômeno são a precipitação de fases oxídicas amorfas e o aparecimento de cargas elétricas na superfície dos grãos do remineralizador durante sua dissolução. Apesar da concentração de $\mathrm{Al}_{2} \mathrm{O}_{3}$ do remineralizador $(11,90 \%)$ e $\mathrm{Fe}_{2} \mathrm{O}_{3}(14,45 \%)$, não houve aumento destes elementos no complexo de troca, possivelmente por sua rápida precipitação em formas amorfas ( $\mathrm{Al}$ e $\mathrm{Fe}$, no solo).

Palavras-chave: pó de rocha, dissolução de minerais, capacidade de troca catiônica.

\section{INTRODUCTION}

Remineralizers (RMs) are powdered rocks that are applied to soil to improve crop performance (STRAATEN, 2006). As humankind has become a geological force on the planet (ZALASIEWICZ, 2008), concern about the exhaustion of natural (including mineral) resources has been raised worldwide (CORDELL et al., 2009; HENGEVELD, 2012; MANNING, 
2015; CHRISTMANN, 2017). Therefore, RMs were included in Brazil's National Mineral Plan to 2030 (BRASIL, 2010), and laws were established to allow them to be registered with the Ministry of Agriculture as a soil amendment (DOU, 2013). Therefore, the processes and mechanisms by which rocks dissolve into the soil must be understood to properly incorporate RMs into soil and crop management.

Impact of RMs in soils is highly dependent on their chemical composition and rate of dissolution. Determining the rate of dissolution of minerals is a scientific challenge per se (MADDOX, 1988; GAUTIER et al., 2001), because of the slow release of elements, the incongruent and nonlinear dissolution of silicates, and the strong dependence of dissolution rates on the nanotopography of mineral surfaces (HODSON, 2006). Considering that RMs are usually rocks with a complex arrangement of minerals, the integration of all these variables into a mechanistic model for their dissolution into soil remains to be done. Lab simulations have significantly increased the knowledge about this issue, but the differences between the dissolution rates measured in laboratory and in the fields remain as high as two orders of magnitude (e.g., WHITE \& BRANTLEY, 2003; PARRY et al., 2015).

Therefore, the objective of this paper was to contribute to this field of study by measuring the chemical changes in a remineralized soil and infer the relationship between the mineralogical and chemical composition of an RM and the changes in soil chemistry.

\section{MATERIALS AND METHODS}

The RM was collected from a mining pit excavated in a sill (22³6'31.2" S; 47'21'45.7" W), whose magmatic differentiation was studied by FARIA (2008). The sill encompasses a wide range of petrochemical types, from monzodiorite to a diabase/basalt, so the mineral chemistry of the remineralizer varies according to the pit sector being mined. In such cases, a thorough characterization of RM load used in the experiment is crucial. The RM analyses presented here were performed on a sample obtained by quartering the load delivered to the experimental field $(5 \mathrm{Mg})$. The total chemical composition of the sample was determined by fusion with $\mathrm{LiBO}_{2} / \mathrm{Li}_{2} \mathrm{~B}_{4} \mathrm{O}_{7}$ at $1000^{\circ} \mathrm{C}$, cooled to a solid disk and further dissolved in $\mathrm{HNO}_{3}+\mathrm{HCl}$ solution, in which the elements were determined by ICP-AES; this sample was run in a batch with 32 others. Batch standard deviation varied from 0 to 0.18 , and the deviation from the internal standard (JB-1) ranged from -0.03 to 0.12 . Particle size distribution was determined according to EMBRAPA (2011) by dispersing the sample with $\mathrm{NaOH}$ and wet sieving. The XRD patterns were obtained with a Rigaku Miniflex II benchtop diffractometer using $\mathrm{CuK}_{\text {alpha }}$ radiation and a graphite monochromator.

The experiment was conducted in an Anionic Acrudox (SOIL SURVEY STAFF. 1999)

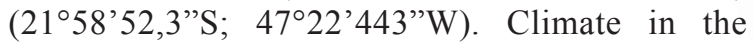
area is Cwa (KOPPEN, 1948) with rainy summers (average precipitation in January of $247.2 \mathrm{~mm}$ ), dry winters (average precipitation in July of $26.9 \mathrm{~mm}$ ) and an average annual precipitation of $1410 \mathrm{~mm}$. The severe dry spell in 2014 was considered the worst in the region in the last 100 years (the total precipitation in 2014 was $1043 \mathrm{~mm}$ ) (Meteorological Station, Universidade de São Paulo campus at Pirassununga-SP).

The experiment began in 2013. Because there is no established method to calculate the RM dose, it was applied at the same rate as lime (4Mg ha$\left.{ }^{1}\right)$. Despite the initial high soil values of exchangeable $\mathrm{K}$ (RAIJ et al., 2001), we decided to include a $\mathrm{K}-\mathrm{KCl}$ treatment to compare the $\mathrm{K}$ partitioning in the soil as a function of the source, and in case the original amount of $\mathrm{K}$ was depleted by plant absorption and soil leaching during the experiment, the difference between the two sources (K-KCl and $\mathrm{K}-\mathrm{RM}$ ) would indicate the exchangeable $\mathrm{K}$ buffering capability of each source.

In 2014, the experiment was converted to monitor the mineralogical transformations of the RM in soil, so a higher concentration of the RM was needed to achieve the minimum concentration necessary to yield a suitable signal/noise ratio in an X-ray diffractometer (MOORE \& REYNOLDS, 1999), which is approximately $5 \%$ volume basis. Therefore, $15 \mathrm{Mg} \mathrm{ha} \mathrm{h}^{-1} \mathrm{RM}$ was applied on the surface of half of the replicates of the previous $4 \mathrm{Mg} \mathrm{ha}^{-1}$ treatment. Consequently, six replications of four treatments were established in 2014 (Table 1): a control (T0); $\mathrm{K}-\mathrm{KCl}$ (T1); the residual of the $4 \mathrm{Mg} \mathrm{ha}^{-1}$ treatment from the previous year, 2013 (T2); and $\mathrm{T} 2$ plus the $15 \mathrm{Mg} \mathrm{ha}^{-1}$ in 2014 . The experimental units were $12 \times 20-\mathrm{m}$ plots, to which the RM was applied by hand at the soil surface without further mixing, and the soil was sampled at the depth of $0-0.05 \mathrm{~m}$ in the central portion of 
Table 1 - Experimental treatments

\begin{tabular}{lcccc}
\hline Treatment & Description $^{*}$ & Applied in November, 2012 & Applied in December, 2013 & Applied in February, 2014 \\
\hline & & --1 & 0 & 0 \\
T0 & Control & 0 & 0 & 135 \\
T1 & $\mathrm{KCl}$ & 0 & 0 & 0 \\
T2 & $\mathrm{RM}$ & 4 & 15 & 0 \\
T3 & $\mathrm{RM}$ & 4 & $\mathrm{~kg}^{-1}$ & 0 \\
\hline
\end{tabular}

All materials applied onto the soil surface without mixing.

plots in line with the plants. This paper presents the monthly monitoring results of soil chemical fertility indexes over 392 days, from December 2013 to December 2014. The experiment was managed according to the no-till scheme used in the entire commercial farm, cropping maize (summer) and black oat (winter).

Soil samples were air dried, crushed and sieved $(2 \mathrm{~mm})$, the $\mathrm{pH}\left(\mathrm{CaCl}_{2} 0.01 \mathrm{~mol} \mathrm{~L}^{-1}\right)$ and the concentrations of exchangeable $\mathrm{Ca}, \mathrm{Mg}, \mathrm{Na}$, $\mathrm{Al}, \mathrm{K}, \mathrm{H}+\mathrm{Al}$ and $\mathrm{Fe}$ were determined (RAIJ et al., 2001). The effective CEC was measured by the compulsive method (CTCef_C) (GILLMAN, 1979), by which the exchange complex is saturated with $\mathrm{Ba}$ using a $\mathrm{BaCl}_{2}$ solution, thus causing a small change in the ionic strength of the soil solution (FONSECA et al., 2005).

The less crystalline forms of $\mathrm{Fe}$ and $\mathrm{Al}\left(\mathrm{Fe}_{\mathrm{o}}, \mathrm{Al}_{\mathrm{o}}\right)$ were selectively extracted using $0,2 \mathrm{~mol} \mathrm{~L}^{-1}$ ammonium oxalate at $\mathrm{pH} 3$ in the dark (SCHWERTMANN, 1964). The pedogenic forms of $\mathrm{Fe}$ and $\mathrm{Al}\left(\mathrm{Fe}_{\mathrm{d}}\right.$ and $\left.\mathrm{Al}_{\mathrm{d}}\right)$ were extracted by four successive extractions with dithionite-citratebicarbonate at $80^{\circ} \mathrm{C}$ (MEHRA \& JACKSON, 1960). For each monitoring event, the differences in $\mathrm{Fe}_{\mathrm{o}}$ and $\mathrm{Al}_{\mathrm{o}}\left(\mathrm{X}_{\mathrm{T}}\right)$ between the treatments and the control (T0) were calculated (Equation 1):

$\mathrm{XT}=\mathrm{Y}_{\mathrm{T}}-\mathrm{Y}_{\mathrm{T} 0}$

Where $\mathrm{Y}$ is $\mathrm{Fe}_{\mathrm{o}}$ or $\mathrm{Al}$, and $\mathrm{T}$ is $\mathrm{T} 3, \mathrm{~T} 2$ or $\mathrm{T} 1$.

A Row-Column design was used to control the spatial variability and the treatments were evaluated over time. Since there was no variance homogeneity for several variables, a mixed model was adjusted, accounting for variance fluctuation at the different time intervals. Statistical analyses were performed using $\mathrm{R}$ software, except for the Tukey test of means, which was done with SAS software. Principal component analysis (PCA) was done with XL STAT software, considering the exchangeable bases, $\mathrm{pH}, \mathrm{Si}, \mathrm{Fe}_{\mathrm{o}}, \mathrm{Al}_{\mathrm{o}}, \mathrm{Fe}_{\mathrm{d}}$ and $\mathrm{Al}_{\mathrm{d}}$.

\section{RESULTS AND DISCUSSION}

The particle size distribution of the RM was $2.7 \%$ gravel, $80.3 \%$ sand, $15.5 \%$ silt and $1.5 \%$ clay. The excess of fine particles makes this material unsuitable for use in concrete and asphalt industries, so it is a co-product with no definite market niche.

The total chemical composition of the RM was 52.10\% $\mathrm{SiO}_{2}, 14.45 \% \mathrm{Fe}_{2} \mathrm{O}_{3}, 11.90 \% \mathrm{Al}_{2} \mathrm{O}_{3}$, $6.94 \% \mathrm{CaO}, 3.45 \% \mathrm{MgO}, 3.06 \% \mathrm{Na}_{2} \mathrm{O}, 1.59 \% \mathrm{~K}_{2} \mathrm{O}$, $3.27 \% \mathrm{TiO}_{2}$ and $0.75 \% \mathrm{P}_{2} \mathrm{O}_{5}$, so the $\mathrm{RM}$ was at the limit between basic and intermediary magmatic rocks $\left(52 \% \mathrm{SiO}_{2}\right)(\mathrm{GILL}, 2015)$. The RM mineralogy, as shown by X-ray diffractometry, was dominated by plagioclases and pyroxens with ilmenite, magnetite, apatite and quartz as accessory minerals (Figure 1). Therefore, we approximated the RM composition to be a diabase. Composition of the plagioclases ranged widely depending on the petrology of the sill sector and also varied from the periphery to the center of each crystal. The periphery of the crystals was more sodic $\left(\mathrm{An}_{12}\right)$ (FARIA, 2008).

As expected from the literature (GILL, 2015), plagioclase was the most abundant (greatest peak in Figure 1) and among the most soluble minerals in the RM (RAMOS et al., 2015). The study by FARIA (2008) demonstrated that the crystal grains are richer in $\mathrm{Na}$ at their periphery 


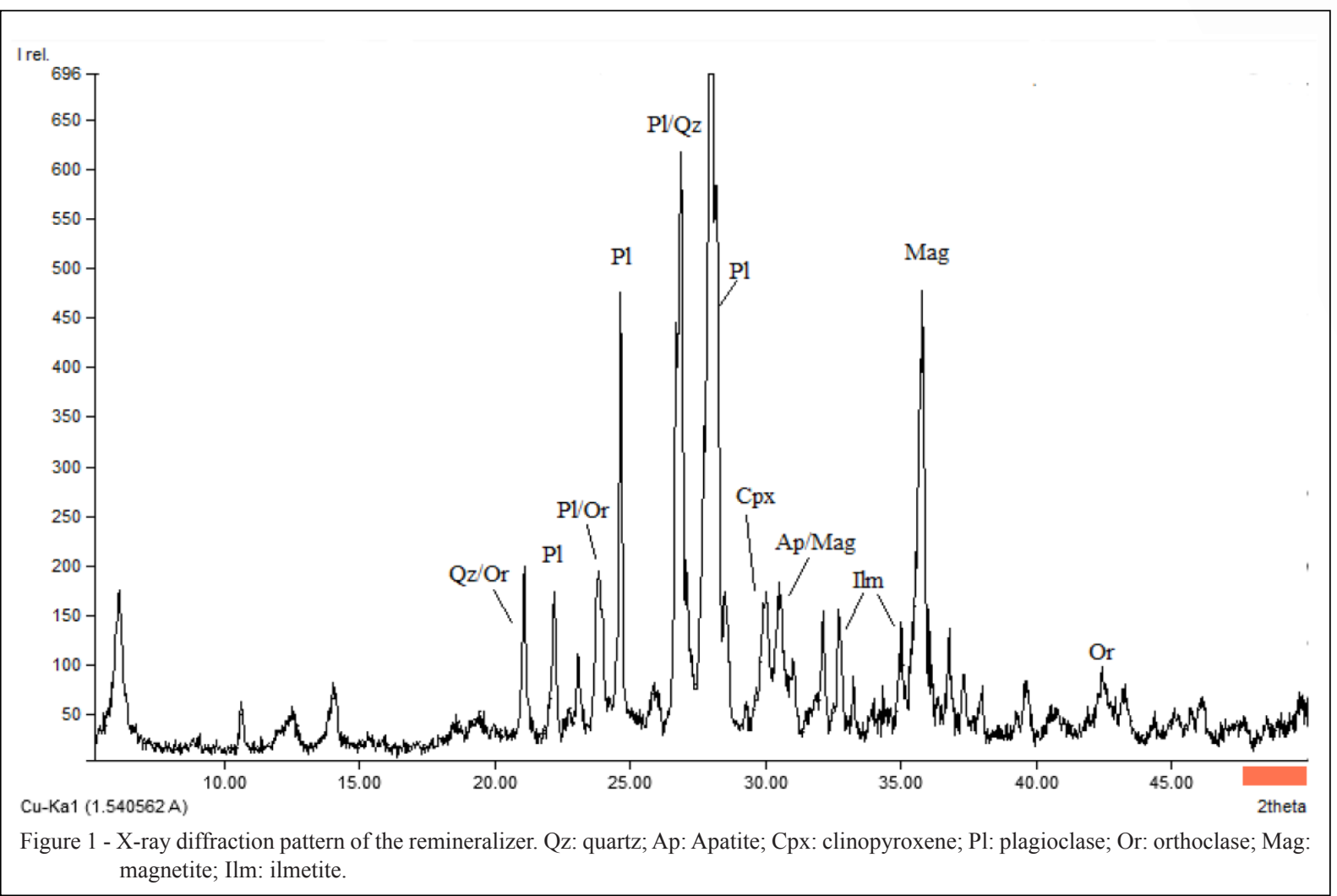

and richer in $\mathrm{Ca}$ at the core, so the composition of the borders is albite (the sodic plagioclase), and the core is anorthite (the calcic plagioclase). Because $\mathrm{Ca}$ and $\mathrm{Na}$ have different ionic radii, some of the atomic planes into the feldspar structure have different distances and thus created separate peaks in the XRD diffractogram (Figure $1)$. Among the minerals in the RM, albite is the only source of $\mathrm{Na}$ and is more soluble than anorthite, so as the plagioclase crystals started to solubilize in the soil, the exchangeable $\mathrm{Na}$ first increased followed by $\mathrm{Ca}$ (Figure 2). The increase was not sufficient to classify the soil as sodic (SANTOS et al., 2013). Compared with T0 and $\mathrm{T} 1$, the difference in exchangeable $\mathrm{Na}$ in the $\mathrm{T} 3$ treatment was higher from day 42 on, except for days 71, 253, 288 and 316, which suggested that the peripheric volume of the plagioclase crystals was being solubilized (Figure 2). The period in which the difference was not significant was probably related to the low precipitation and leaching during the dry winter (day 253 was in August, 288 in September and 316 in October). Based on this reasoning, the $\mathrm{Ca}$ cores of the plagioclases were not or only slightly solubilized since the exchangeable Ca was only greater in T3 in April (day 128), May (day 161) and September (day 288). However, it is not possible to know this for sure because $\mathrm{Ca}$ ions have additional sources in other minerals (e.g., apatite) compared to $\mathrm{Na}$. In the $\mathrm{T} 2$ treatment, the exchangeable $\mathrm{Na}$ was only greater than $\mathrm{T} 1$ and T0 on day 224 (July), suggesting that, despite the smaller dose $\left(4 \mathrm{Mg} \mathrm{ha}^{-1}\right)$ and the longer duration (two years), some albite is still being dissolved from the crystal borders. The exchangeable $\mathrm{Ca}$ in the control (T0) remained between approximately 20 and $40 \mathrm{mmolc} \mathrm{dm}^{-3}$ throughout the experiment (except in March, day 101), while it reached almost $60 \mathrm{mmolc} \mathrm{dm}^{-3}$ in T3 in September (day 288). 


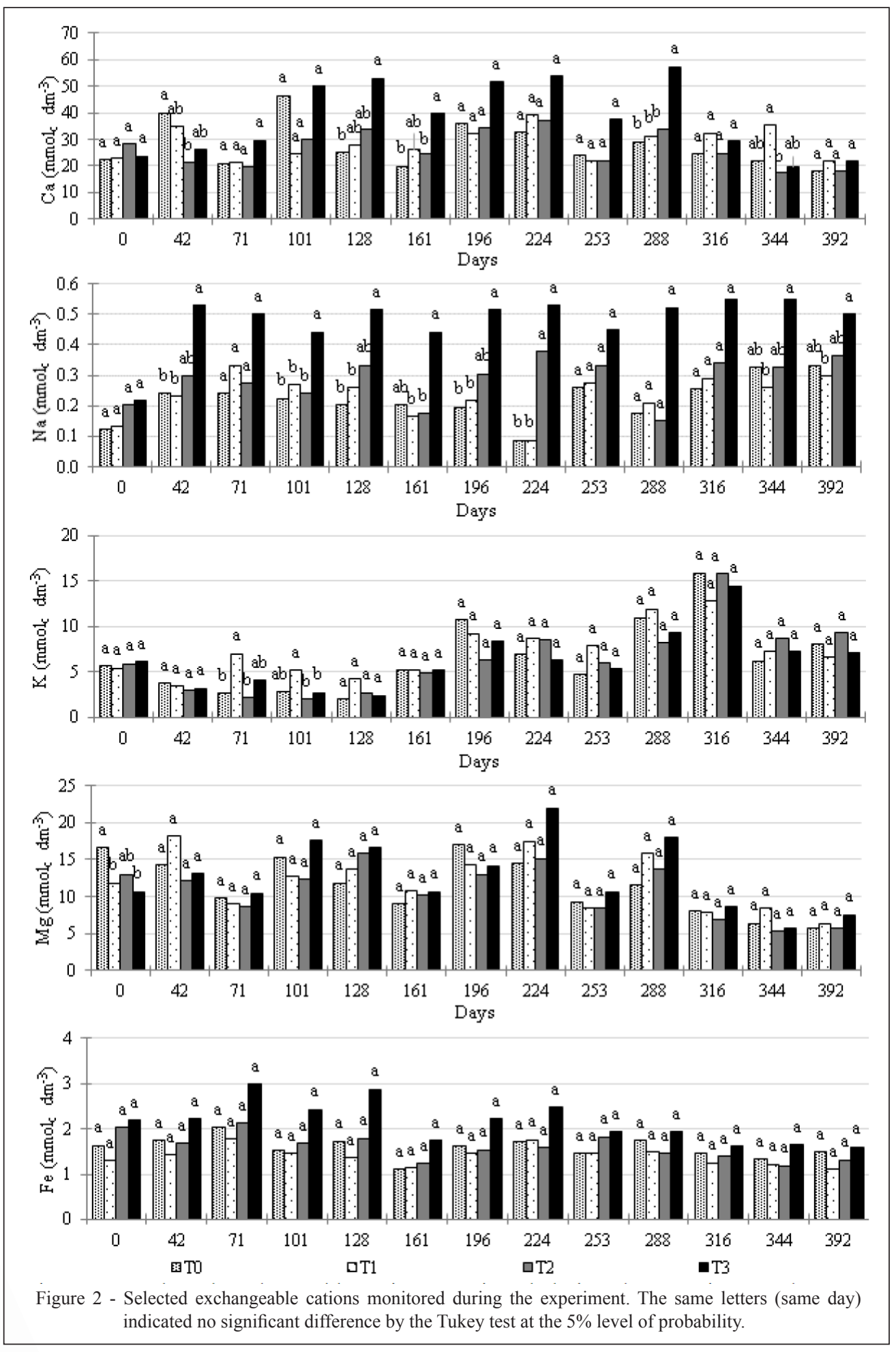

Expectation to observe some effect of the $\mathrm{K}$ source on the K-buffering capability (see
Materials and Methods) was not realized. There 1 was no difference among treatments, except for the 2 
monitoring at days 71 and 101, but this effect was due to the application of $\mathrm{KCl}$ in the days before (Table 1) due to the regular management of the farm. This result showed that $\mathrm{K}-\mathrm{KCl}$ application increased the exchangeable $\mathrm{K}$ during the following two months. The short-term performance of the $\mathrm{RM}$ as a source of $\mathrm{K}$ was expected to be low since the amount of $\mathrm{K}$-feldspars in the RM is small, and they have lower solubility than the $\mathrm{Na}-\mathrm{Ca}$ feldspars (plagioclases) (BARRAL SILVA, 2005; MANNING, 2010).

The pyroxens were the main source of $\mathrm{Mg}$ and one of the sources of Fe. Pyroxens are a relatively soluble group of minerals, but their concentration in the RM was low (Figure 2). An additional source of Fe was the primary iron oxides (ilmenite, magnetite, Figure 1), which were present as accessory minerals and thus also at low concentrations. However, the dissolution of metal oxides is known to be generally congruent as opposed to the usually incongruent dissolution of silicates. Lack of an increase in exchangeable Fe suggested that most of the Fe ions in solution readily precipitated as amorphous iron oxides, which was supported by the increase in $\mathrm{Fe}_{\mathrm{o}}$ (Figure 3). This mechanism was expected because of the very low solubility of the ferric ion $\left(\mathrm{Fe}^{+3}\right)$ (LINDSAY, 1979).

The average soil $\mathrm{pH}$ during the experiment was 5.5, and the range in $\mathrm{pH}$ variation was approximately 2 , that is, $5.53 \pm 2.03$ in T0, $5.71 \pm 2.08$ in $\mathrm{T} 1,5.66 \pm 2.08$ in $\mathrm{T} 2$ and $5.75 \pm 2.10$ in $\mathrm{T} 3$. The increase/decrease in $\mathrm{pH}$ was roughly parallel among treatments (not shown). In each single monitoring event, difference among treatments was not greater than $0.7 \mathrm{pH}$ units. Weathering of silicates consumes $\mathrm{CO}_{2}$ and tends to increase the $\mathrm{pH}$ up to the dissociation constant of the first $\mathrm{H}$ of silicic acid $\left(\mathrm{H}_{4} \mathrm{SiO}_{4}\right)$, that is, a $\mathrm{pH}$ of approximately 9 (McBRIDE, 1994), but this effect seemed to be overruled by the buffering capacity of the soil acidity.

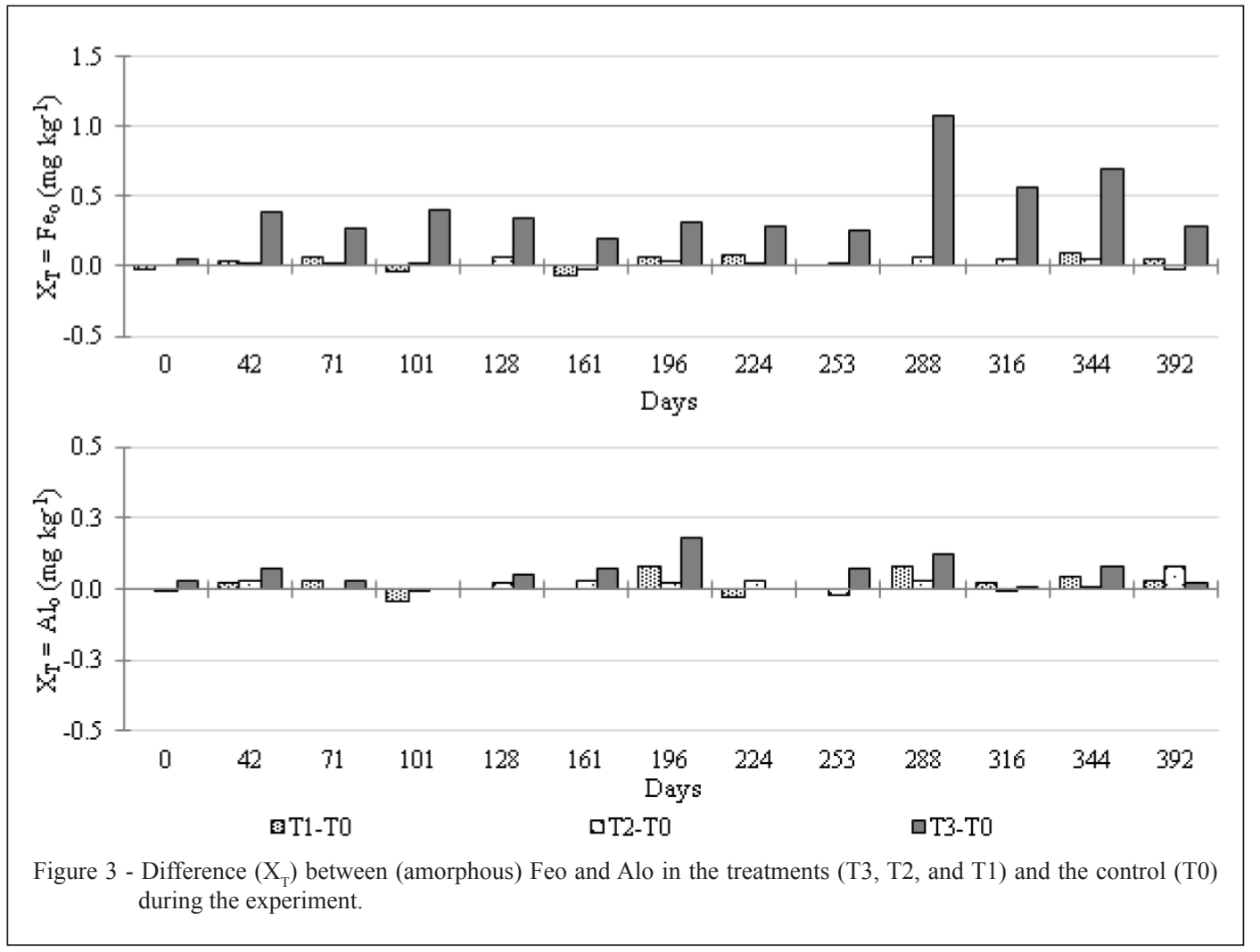

Ciência Rural, v.47, n.11, 2017. 
The CECef-C was greater in $\mathrm{T} 2$ from day 101 to day 288, and the $\mathrm{pH}$ did not change significantly relative to the other treatments. The greatest increase was $9 \mathrm{mmol}_{\mathrm{c}} \mathrm{kg}^{-1}$ in $\mathrm{T} 2$, compared to T0, at day 101 (Figure 4). Two nonexclusive hypotheses are proposed to explain these differences: i) an increase in CECef-C due to the precipitation of amorphous phases and ii) the development of CECef-C on the surface of the RM grains during the weathering of primary minerals. The observed precipitation of amorphous $\mathrm{Fe}$ and $\mathrm{Al}\left(\mathrm{Fe}_{\mathrm{o}}\right.$ and $\mathrm{Al}$, Figure 3 ) does not support hypothesis i) since it was greater in $\mathrm{T} 3$ than in T2, while the CECef-C was greater in $\mathrm{T} 2$.

The precipitation of Al was possibly the main sink of the exchangeable Al released from the RM, which would explain why no increase in exchangeable Al was detected (not shown, but it was $2 \mathrm{mmol}_{\mathrm{c}} \mathrm{dm}^{-3}$ or less in all samples) despite the high content of $\mathrm{Al}$ in the RM $(13.9 \%$ of $\mathrm{Al}_{2} \mathrm{O}_{3}$ ). Lack of an increase in exchangeable $\mathrm{Al}$ is a common finding in previous studies (GILLMAN et al., 2001; ANDA et al., 2009; RAMOS et al., 2014 and 2015).

The principal component analysis resulted in the association of $87.17 \%$ of the variation with the $\mathrm{F} 1$ axis and $91.58 \%$ of the variation with the sum of the first two components (axis F1 + axis F2) (Figure 5). The T3 points are on the right side of the F1 axis, while the others are grouped near the origin of the axis (Figure 5a); the results are better illustrated through the centroids (Figure $5 b)$. Variables that contributed the most to F1 were $\mathrm{Fe}_{\mathrm{o}}$ (total) and $\mathrm{Na}$. Variables $\mathrm{Mg}, \mathrm{Fe}$ and $\mathrm{Ca}$ were also highly correlated with each other; these five variables were the most important in changing the chemical characteristics of the soil.

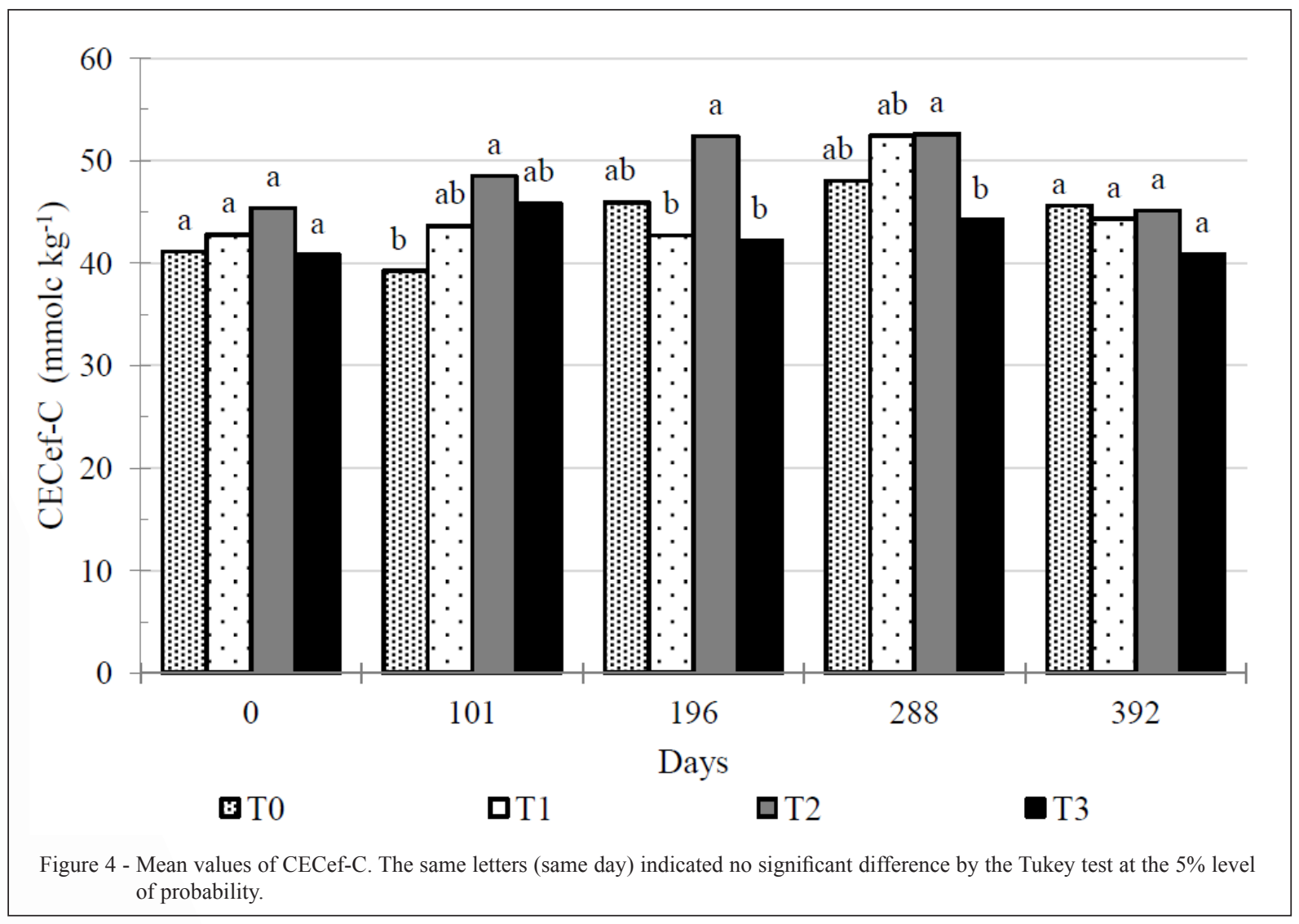

Ciência Rural, v.47, n.11, 2017. 


\section{CONCLUSION}

Knowing the detailed chemical and mineral composition of the RM helped relate it to the great increase in exchangeable $\mathrm{Na}$ during the experiment. The late increase in exchangeable $\mathrm{Ca}$ was possibly related to its concentration in the cores of the plagioclases but also to the slow dissolution of the other mineral sources within the RM. Variation in $\mathrm{pH}$ could not be associated with the variation in CECef, so at least two hypotheses to explain its increase remain to be tested. Lack of increase in

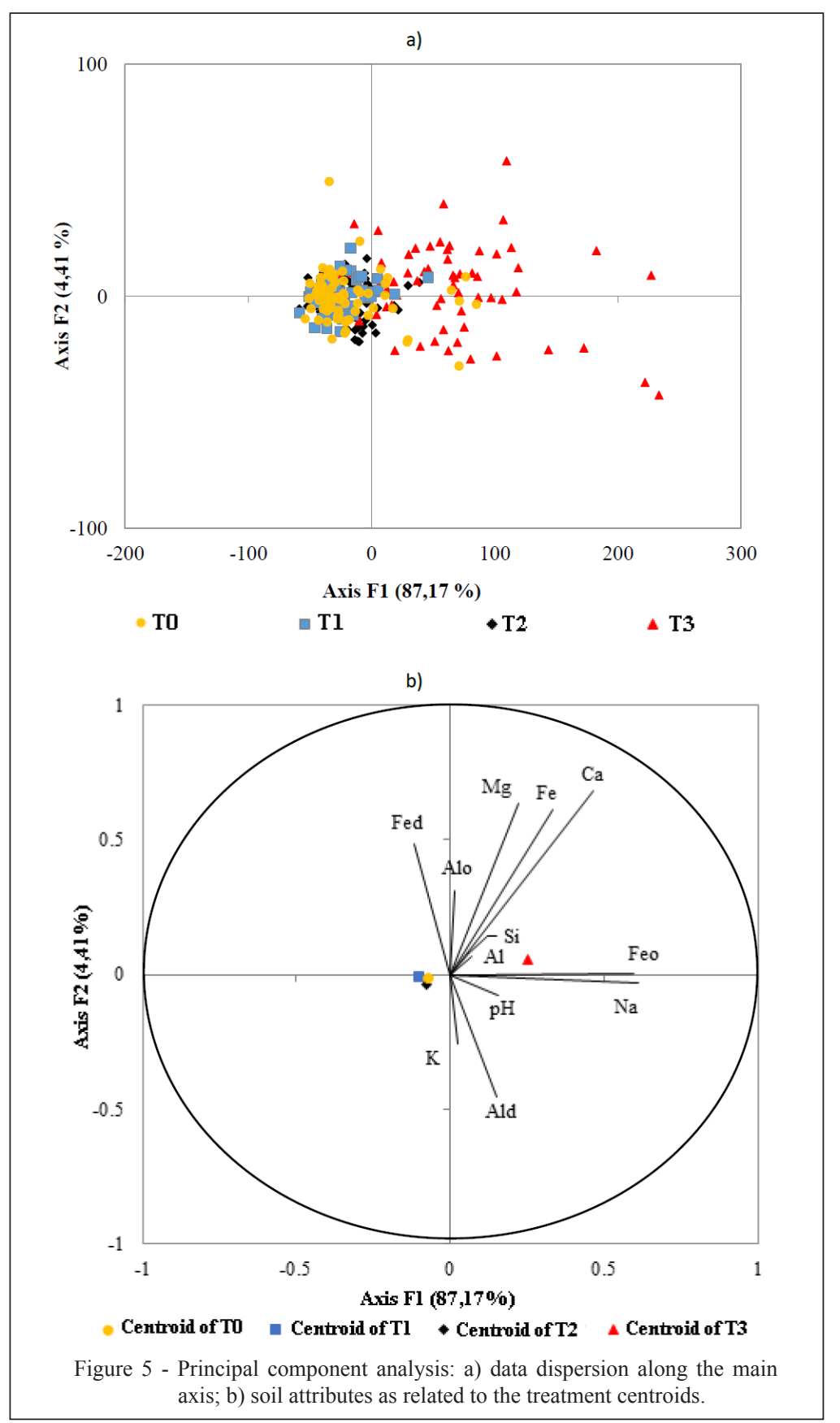

Ciência Rural, v.47, n.11, 2017. 
exchangeable forms of $\mathrm{Fe}$ and $\mathrm{Al}$ was possibly due to their precipitation as amorphous phases.

\section{ACKNOWLEDGEMENTS}

To Coordenação de Aperfeiçoamento de Pessoal de Nível Superior (CAPES) (PROEX to RCS), Fundação de Amparo a Pesquisa do Estado de São Paulo (FAPESP) (BIC FAPESP 2014/10057-2 to MEC) Conselho Nacional de Desenvolvimento Científico e Tecnológico (CNPq) (research funding 406600/2013-9 and research grants PQ 305725/2012-2 to ACA and DTI 380451/20140 to JJCI), Figueira Branca Farm and Cavinatto Mining.

\section{REFERENCES}

ANDA, M. et al. Assessing parent material uniformity of a red and black soil complex in the landscapes. Catena, v.78, p.142-153, 2009. Available from: <http://dx.doi.org/10.1016/j.catena.2009.03.011>. Accessed: Oct. 17, 2016. doi: 10.1016/j.catena.2009.03.011.

BARRAL SILVA, M.T. et al. Reutilization of granite powder as an amendment and fertilizer for acid soils. Chemosphere, v.61, p.993-1002, 2005. Available from: <http://www.sciencedirect.com/ science/article/pii/S0045653505004121>. Accessed: June, 06, 2016. doi: 10.1016/j.chemosphere.2005.03.010.

BRASIL, Ministério de Minas e Energia. Plano Nacional de Mineração 2030 (PNM - 2030). Brasília: MME, 2010. 178p.

DIÁRIO OFICIAL DA UNIÃO - DOU. Lei 12.890, de 10 de Dezembro de 2013. Publicado em 11/12/2013. Ano CL, n.240, 2013. 1p.

EMBRAPA. Manual de métodos de análise de solos. In: DONAGEMA G.K. et al. (Orgs.). Dados eletrônicos. Rio de Janeiro: Embrapa Solos, 2011. 230p. Available from: <https://www.infoteca.cnptia.embrapa br/bitstream/doc/990374/1/ManualdeMtodosdeAnilisedeSolo.pdf>. Online. Accessed: September, 11, 2016

CHRISTMANN, P. Towards a more equitable use of mineral resources Natural Resources Research,v.?,p.1-19,2017.Available from: $<$ https:// link.springer.com/content/pdf/10.1007\%2Fs11053-017-9343-6.pdf>. Accessed: July 07, 2017. doi: 10.1007/s11053-017-9343-6.

CORDELL, D. et al. The story of phosphorus: global food security and food for thought. Global Environmental Change, v.19, p.292-305, 2009. Available from: <http://www.sciencedirect.com/ science/article/pii/S095937800800099X >. Accessed: July 20, 2017. doi: 10.1016/j.gloenvcha.2008.10.009.

FARIA, C.A. Evolução magmática do sill de Limeira: petrologia e geoquímica. 2008. 106f. Dissertation (Master in Geoscience) Universidade de São Paulo, Geoscience Institute, São Paulo, SP.

FONSECA, A.F. et al. Cation exchange capacity of an oxisol amended with an effluent from domestic sewage treatment. Scientia Agricola, v.62, p.552-558, 2005. Available from: $<$ http:// dx.doi.org/10.1590/S0103-90162005000600007>. Accessed: Oct. 17, 2016. doi: 10.1590/S0103-90162005000600007.

GAUTIER, J.M. Are quartz dissolution rates proportional to B.E.T. surface areas? Geochimica et Cosmochimica Acta, v.65, p.1059-1070, 2001. Available from: <http://www.sciencedirect. com/science/article/pii/S0016703700005706> . Accessed: July 20, 2017. doi: 10.1016/S0016-7037(00)00570-6.
GILL, R. Rochas e processos igneos (Igneous rocks and processes). Brazil: Bookman, 2015. 427p.

GILLMAN, G.P. A proposed method or the measurement of exchange properties of highly weathered soils. Australian Journal of Soil Research, v.17, p.129-139, 1979. Available from: <http://dx.doi.org/10.1071/ SR9790129>. Accessed: Sept. 28, 2015. doi: 10.1071/SR9790129.

GILLMAN, G.P. et al. A laboratory study of application of basalt dust to highly weathered soils: effect on soil cation chemistry. Australian Journal of Soil Research, v.1, p.799-811, 2001. Available from: $<$ http://dx.doi.org/10.1071/SR00073>. Accessed: June 28, 2015. doi: 10.1071/SR00073.

HENGEVELD, R. Wasted world: how our consumption challenges the planet. USA: University of Chicago, 2012. 356p.

HODSON, M.E. Does reactive surface area depend on grain size? Results from $\mathrm{pH} 3,25^{\circ} \mathrm{C}$ far-from-equilibrium flow-through dissolution experiments on anorthite and biotite. Geochimica et Cosmochimica Acta, v.70, p.1655-1667, 2006. Available from: <https://doi.org/10.1016/j.gca.2006.01.001>. Accessed: July 10, 2017. doi: 10.1016/j.gca.2006.01.001

KÖPPEN, W. Climatologia: con un estudio de los climas de la tierra. Mexico: Fondo de Cultura Econômica, 1948. 479p.

LINDSAY, W.L. Chemical Equilibria in Soils. New York: Willey Interscience, 1979. 449p.

MADDOX, J. Crystals from first principles. Nature, v.335, p.201, 1988. Available from: <https://www.nature.com/nature/journal/v335/ n6187/pdf/335201a0.pdfhttp://link.springer.com/article/10.1051/ agro/2009023 > . Accessed: July 10, 2017. doi: 10.1038/345297a0.

MANNING, D.A.C. How will minerals feed the world in 2050 ? Proceedings of the Geologist's Association, v.126, p.14-17, 2015. Available from: $<$ https://doi.org/10.1016/j.pgeola.2014.12.005http:// link.springer.com/article/10.1051/agro/2009023>. Accessed: July 10, 2017. doi: 10.1016/j.pgeola.2014.12.005.

MANNING, D.A.C. Mineral sources of potassium for plant nutrition. A review. Agronomy for Sustainable Development, v.30, p.281-294, 2010. Available from: <http://link.springer.com/ article/10.1051/agro/2009023>. Accessed: June 28, 2015. doi: $10.1051 /$ agro/2009023.

McBRIDE, M.B. Environmental chemistry of soils. New York: Oxford University, 1994. 416p.

MEHRA, O.P.; JACKSON, M.L. Iron oxide removal from soils and clays by a dithionite-citrate system buffered with sodium bicarbonate. London, 1960. In: NATIONAL CONFERENCE ON CLAYS AND CLAYS MINERALS, 7., 1960, London. Proceedings... London: Geoscience Word, 1960. v.7, p.317-327.

MOORE, D.M.; REYNOLDS, R.C. X-ray diffraction and identification and analysis of clay minerals. 2.ed. Oxford: Oxford University, 1997. 378p.

PARRY, S.A. et al. The surface area and reactivity of granitic soils: I. Dissolution rates of primary minerals as a function of depth and age deduced from field observations. Geoderma, v.237238, p.21-35, 2015. Available from: <https://doi.org/10.1016/j. geoderma.2014.08.004>. Accessed: July 10, 2017. doi: 10.1016/j. geoderma.2014.08.004 
RAIJ, B. Van. et al. Análise química para avaliação da fertilidade de solos tropicais. Campinas: Instituto Agronômico, 2001. 285p.

RAMOS, C.G. et al. A preliminary study of acid volcanic rocks for stonemeal application. Environmental Nanotechnology, Monitoring \& Management, v.1-2, p.30-35, 2014. Available from: $<$ https://doi.org/10.1016/j.enmm.2014.03.002>. Accessed: June 25, 2016. doi: 10.1016/j.enmm.2014.03.002.

RAMOS, C.G. et al. A preliminary evaluation of volcanic rock powder for application in agriculture as soil a remineralizer. Science of the Total Environment, v.512-513, p.371-380, 2015. Available from: $<$ https://doi.org/10.1016/j.scitotenv.2014.12.070>. Accessed: June 28, 2016. doi: 10.1016/j.scitotenv.2014.12.070.

SANTOS, H.G. et al. Sistema brasileiro de classificação de solos. 3.ed. rev. ampl. Brasília: Embrapa, 2013. 353p.

SOIL SURVEY STAFF. Soil taxonomy: a basic system of soil classification for making and interpreting soil surveys. 2 ed. USA: Natural Resources Conservation Service. U.S. Department of Agriculture Handbook, 1999. 436p.
STRAATEN, P. van. Farming with rocks and minerals: challenges and opportunities. Annals of the Brazilian Academy of Sciences, v.78, p.732-747, 2006. Available from: <http://dx.doi.org/10.1590/ S0001-37652006000400009>. Accessed: Sept. 28, 2015. doi: 10.1590/S0001-37652006000400009.

SCHWERTMANN, U. Differenzierung der eisenoxide des bodens durch extraktion mit ammoniumoxalat lösung. Z. Pflanzenern. Düng. Bodenk, v.105, p.194-202, 1964. Available from: <http:// onlinelibrary.wiley.com/doi/10.1002/jpln.3591050303/full>. Accessed: June 28, 2015. doi: 10.1002/jpln.3591050303.

WHITE, A.F.; BRANTLEY, S.L. The effect of time on the weathering of silicate minerals: why do weathering rates differ in the laboratory and field? Chemical Geology, v.202, p.479-506, 2003. Available from: <http:// www.sciencedirect.com/science/article/pii/S0009254103002560>. Accessed: June 28, 2015. doi: 10.1016/j.chemgeo.2003.03.001.

ZALASIEWICZ, J. et al. Are we now living in the Anthropocene? GSA Today, v.18, n.2, p.4-8, 2008. Available from: $<$ https://www.geosociety. org/gsatoday/archive/18/2/pdf/11052-5173-18-2-4.pdfhttp://www. sciencedirect.com/science/article/pii/S0009254103002560>. Accessed: July 20, 2017. doi: 10.1130/GSAT01802A.1. 